\title{
経験的グリーン関数法を用いた 2016年鳥取県中部の地震の震源のモデル化
}

池田 隆明 1 - 染井 一寛 2 - 倉橋 奨 3 - 宮腰 研 4 - 釜江 克宏 5 ・

高瀬 裕也 6 ・ 小島 由記子7

1正会員 長岡技術科学大学教授 大学院工学研究科原子カシステム安全工学専攻

( ( 940-2188 新潟県長岡市上富岡町1603-1)

E-mail: ikeda@vos.nagaokaut.ac.jp

2地域地盤環境研究所研究員（干 540-0008 大阪府大阪市中央区大手前2-1-2）

E-mail: somei@geor.or.jp

3正会員 愛知工業大学講師 工学部土木工学科（广470-0392 愛知県豊田市八草町八千草1247）

E-mail: susumu@aitech.ac.jp

4地域地盤環境研究所グループリーダー（†540-0008 大阪府大阪市中央区大手前2-1-2）

E-mail: ken@geor.or.jp

5京都大学教授 原子炉実験所（广590-0494 大阪府泉南郡熊取町朝代西2丁目）

E-mail: kamae@rri.kyoto-u.ac.jp

6正会員 室蘭工業大学准教授 大学院工学研究科 $く$ し環境系領域

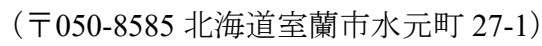

E-mail: y.takase@mmm.muroran-it.ac.jp

7 正会員 長岡工業高等専門学校助教 環境都市工学科（下940-8532 新潟県長岡市西片貝町888番地）

E-mail: y_kojima@nagaoka-ct.ac.jp

2016年10月21日に鳥取県中部でMj6.6の地震が発生し, 震源近傍では強い地震動が生じ多くの住家被害 が発生した, この地震は従来活断層が確認されていなかった場所で発生したものであり, 強震動予測にお いては「震源を事前に特定できない地震」のタイプに分類される. 我が国にはこのようなタイプの地震が 発生する可能性が高く, 震源のモデル化を含めた強震動予測技術の精度の向上が求められる. そこで, 経 験的グリーン関数法を用いたフォワードモデリングにより鳥取県中部の地震の震源モデルを構築し, 既往 の震源のモデル化手法との比較を行った.

Key Words : the Central Tottori prefecture earthquake, empirical Green's function method, source model, strong motion generation area, blind faults in the upper crust, scaling law

\section{1. はじめに}

2016年10月21日14時07分頃，鳥取県中部を震源とする $M \mathrm{j} 6.6$ の地震が発生した（以下，本地震，もしくは鳥取 県中部の地震) 。震源近傍では強い地震動が観測され， 震度6弱を観測した倉吉市，東伯郡湯梨浜町，同郡北栄 町を中心に全壞18棟を含む15,367棟の住家被害が発生し た．また，震源近傍を中心に河川，道路，橋梁等の土木 施設・構造物にも複数の被害が発生した ${ }^{1)}$.

余震分布およびメカニズム解2) 3)，干涉SARによる地款 変動の分布パターン4)より震源断層は北北西一南南東方
向に延びる高角の左横ずれ型と考えられる.

本地震の震源の東側には1943年鳥取地震（Mj7.2）の 震源断層と考えられる鹿野一吉岡断層や岩坪断層, 南東 側には山崎断層帯の西端を構成する那岐山断層帯が確認 されているが，震源近傍に明瞭な活断層は確認されてい ない.

1983年に本地震の震源の東側でMj6.2の地震が発生し ている.この地震は1943年鳥取地震を引き起こしたと考 えられる鹿野一吉岡断層の西端で発生しており, 余震分 布等から震源断層は鹿野一吉岡断層の走向に共役な北北 西一南南東に走向を有する左横ずれ型5) と想定されてい 
る.また本地震の震源域から西側に $50 \mathrm{~km}$ 程度離れた地 域では2000年鳥取県西部地震が発生している. この地震 も本地震および前述の地震と同じく北北西一南南東に走 向を有する左横ずれ型である。地震規模はMj7.3 と 1995 年兵庫県南部地震や2016年熊本地震（4月16日1時25分頃 に発生した地震) と同じで, 内陸地殼内地震としては規 模が大きい地震であったが，本地震と同様に明瞭な活断 層が確認されていない場所で発生したと考えられている.

将来発生する地震被害の軽減を目的に, 強震動予測の 高度化に関する研究が精力的に進められているの. 震源 を事前に特定できない地震の地震動の上限レベルについ ては加藤らかが地質学的調査による地震の分類と強震観 測記録に基づき検討しているが，本地震および2000年鳥 取県西部地震の発生を考えると，「震源を事前に特定で きない地震」に対して, 既往の強震動予測手法の適用性 を検討することは重要と考えられる.

そこで本稿では，2016年鳥取県中部の地震の震源モデ ルを経験的グリーン関数法8)を用いたフォワードモデリ ングクにより構築し，震源モデルの震源特性について既 往の震源のモデル化手法のとの比較を行う.

\section{2. 地震の概要}

表-1に2016年鳥取県中部の地震の概要, 図-1に本震お よび本震後48時間以内に発生した余震の震央分布を示寸 本震についてはF-net²のメカニズム解も併せて示す．余 震の震央は北北西一南南東方向に分布していることがわ かる. 図中には1983年10月31日に発生したMj6.2の地震の 震央と本震後3ヶ月間に発生した余震の震央分布を示す. $M j 6.2$ 地震の余震分布は本地震の余震分布と同じく北 北西一南南東方向に分布していることがわかる.

\section{3. 震源近傍の地震動とその特徴}

本地震における震源近傍を含む広域の地震動記録が防 災科学技術研究所の強震観測網 (K-NET, KiK-net) ${ }^{10)}$, 気象庁 ${ }^{11)}$, 地方公共団体 ${ }^{12)}$ の地震計で得られている. 図2に本地震の震央位置と周辺の地震観測地点を示寸.

震源近傍の鳥取県の三朝町観測点（81022） と北栄町 観測点（81024），気象庁の倉吉観測点（CE4），K-NET 上斎原（OKY015）で観測された地震動の加速度および 速度波形を図-3に示す。速度波形は加速度波形に $0.1 \mathrm{~Hz}$ 〜10.0Hzのバンドパスフィルターを作用させた後，フー リエ積分により算出した．図-3の時間軸の0秒は14時07 分10秒である.

81024地点とOKY015は断層の走向方向に位置する観測

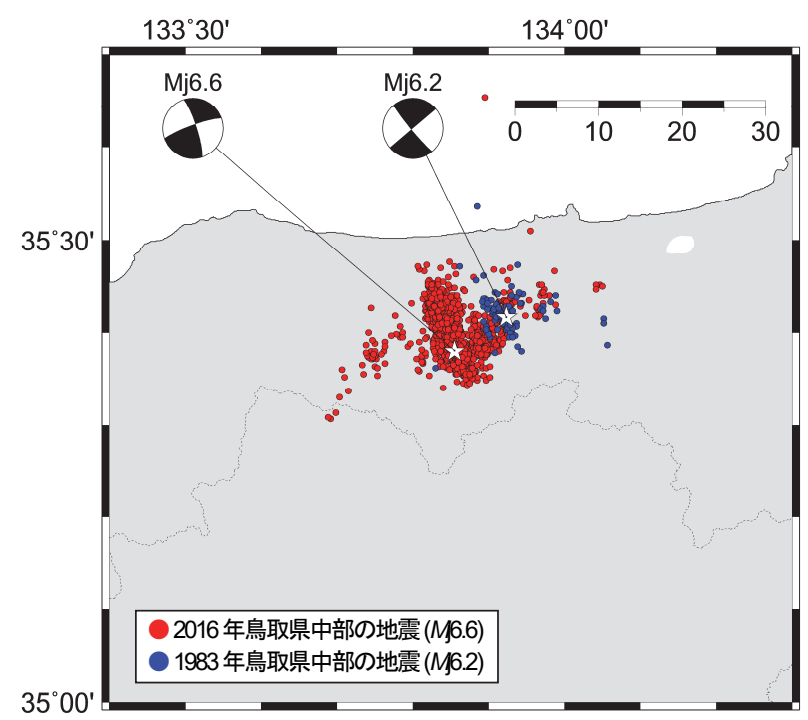

図-1 2016 年鳥取県中部の地震の震央と余震の震央分布 $(48$ 時間以内），および 1983 年 10 月 31 日に発生した Mj6.2 の地震の震央と余震の震央分布（3力月以内）

表-1 2016年鳥取県中部の地震の概要,

\begin{tabular}{cc}
\hline 発生日時 & 2016年10月21日14時07分22.5秒 \\
\hline 震央 & $35^{\circ} 22.83^{\prime} \mathrm{N} 133^{\circ} 51.37 \mathrm{E}$ \\
\hline 深さ & $10.61 \mathrm{~km}$ \\
\hline マグニチュード & $M \mathrm{j} 6.6, M \mathrm{w} 6.2^{2)}$ \\
\hline 地震モーメント & $2.24 \times 10^{18} \mathrm{~N} \cdot \mathrm{m}$ \\
\hline STR/DIP/RAK & \\
\hline
\end{tabular}

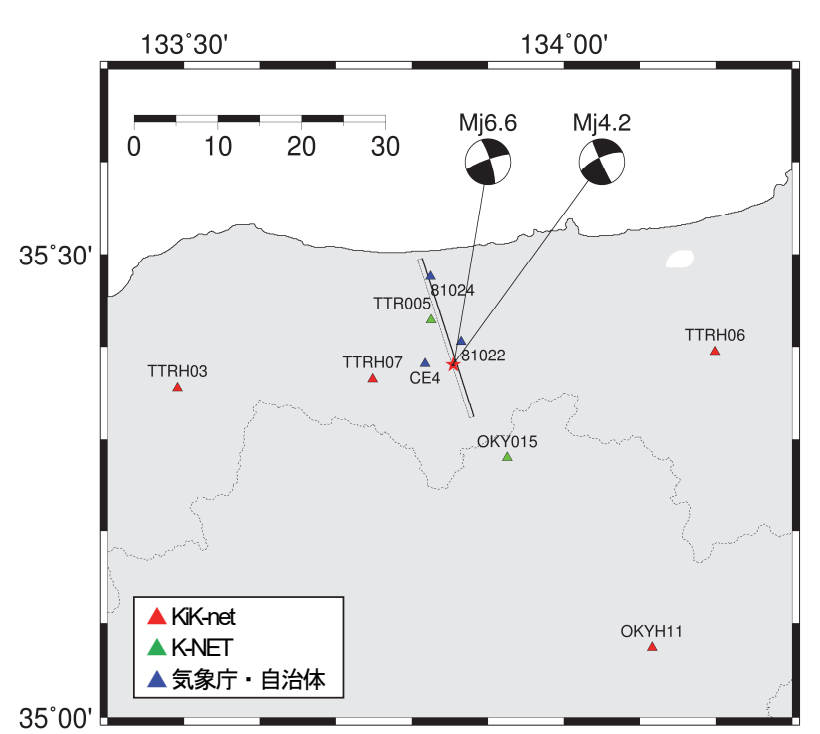

図-2 2016 年鳥取県中部の地震の震央と想定断層面, 経験的 グリーン関数イベントに用いた要素地震の震央, およ び震源周辺の地震観測地点

地点である. 破壊開始点からの距離はほぼ同じであるが, 観測された地震動には大きな差異が見られる。破壊開始 点の北側に位置する81024地点の波形にはパルス状の波 形が見られるのに対して，南側に位置するOKY015の波 形にはパルス状の波形は見られない. また, 主要動の継 
続時間は81024地点に対してOKY015の方が長いことが見 て取れる.この結果は破壊開始点から始まった震源破壊 が北側に進行したことを示唆するものと考えられ， 81024地点で見られたパルス状の波形は震源破壊の指向 性効果によるものと考えられる.

81022地点とCE4地点は走向直交方向に位置する震源近 傍の観測地点であり，両地点とも速度波形の前半部にパ ルス状の波形が見られる．図-2には後述する想定断層面 を示している．想定断層面の走向は162度であるため, NS成分は走向方向，EW成分が走向直角方向に相当する。 81022地点は断層の東側に, CE4地点は断層の西側に位置 するため走向方向に相当するNS成分のパルス波形の方 向は相反している. 次章で説明するが波形インバージョ ン解析では震源（破壊開始点）付近に大きな寸べり領域

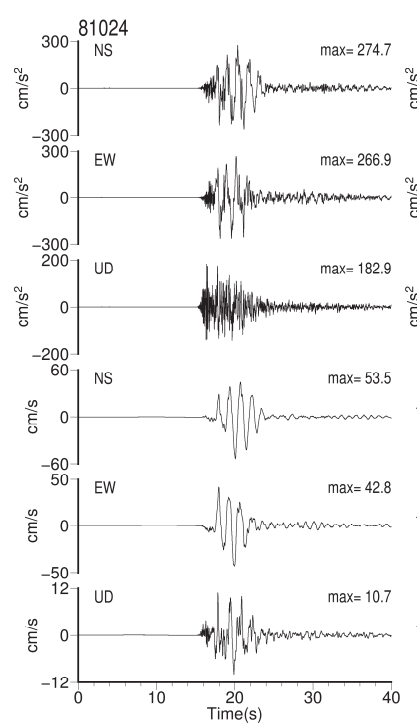

(a)81024地点

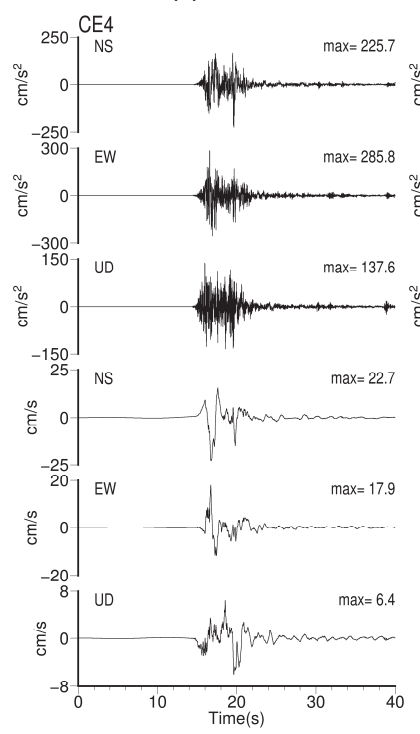

(c)CE4地点

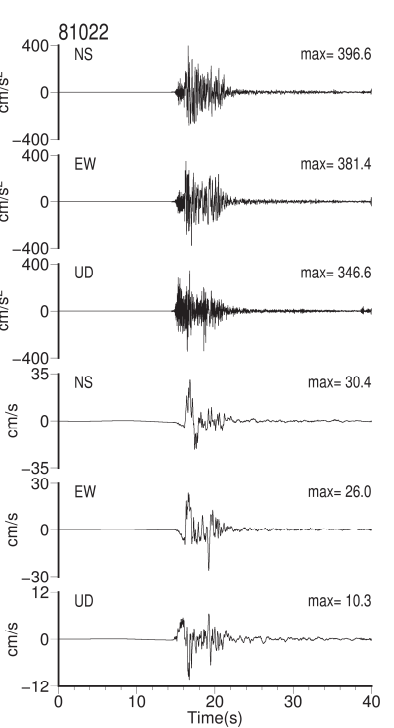

(b)81022地点

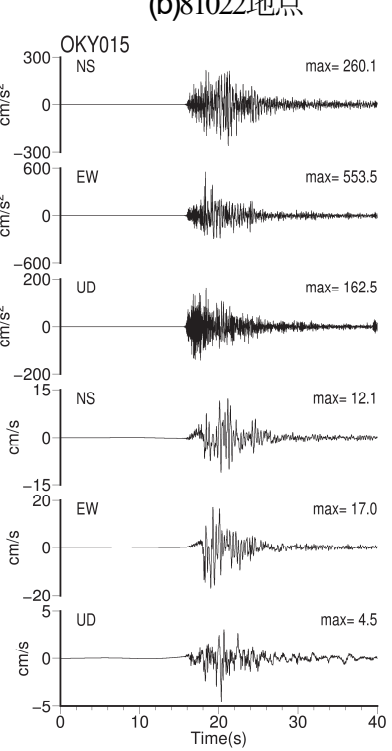

(d)OKY015
図-3 震源近傍の地震観測地点で観測された 2016年鳥取県中 部の地震の時刻歴波形
があり，震源付近が主要な破壊領域と考えられる.そこ で，震源を通るように想定断層面に共役な面を設定する と81022地点とCE4地点はともに共役な面の北側に位置す る. そのためEW成分のパルス波形の方向は一致してい る.このように，震源近傍地点で観測された地震動波形 には震源破壊の指向性効果や震源放射特性の影響が含ま れていると考えられる.

\section{4. 震源の破壊過程}

2016年鳥取県中部の地震の震源破壊過程が複数の研究 者により報告されている。ここでは，周辺のK-NET，

KiK-netにより得られた近地強震記録を用いた波形インバ ージョンに基づく久保ら ${ }^{13)}$ ，小林ら ${ }^{14)}$ の結果について比 較する. 図-4に二つの研究で得られた最終すべり量分布 を比較して示す：二つのモデルとも，F-netの暫定解を使 用したため（走向162度），断層面基準点は北端となっ ている. 久保らの方が最大すべり量が発生した深さが浅 いという違いはあるが，双方とも破壊開始点から浅い領 域にかけて大きなすべりが得られている.また，震源近

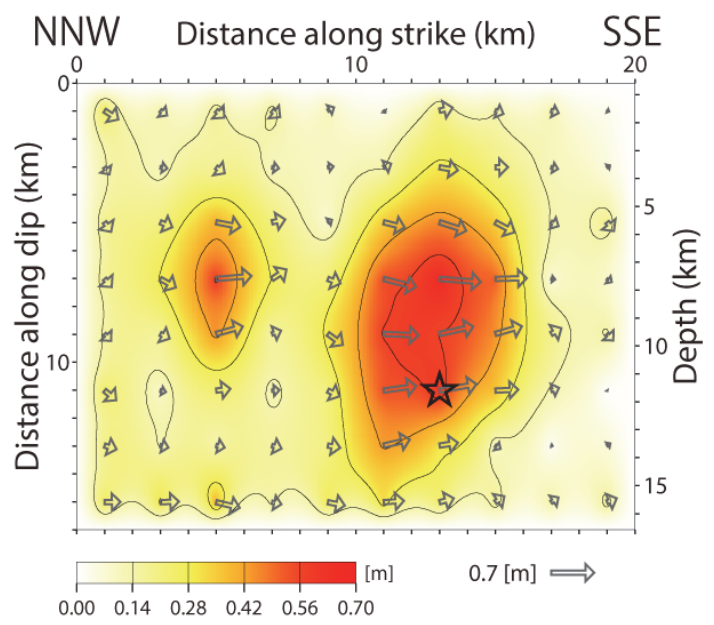

(a)久保 $5^{13)}$

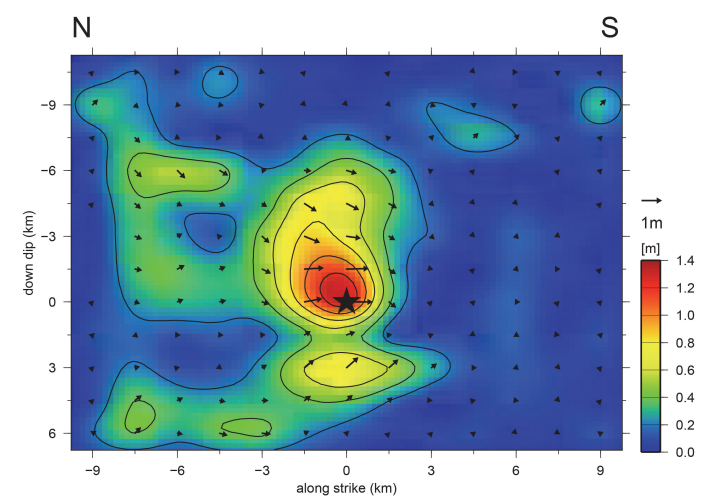

(b)小林ら ${ }^{14)}$

図-4 波形インバージョン解析による 2016 年鳥取県中部の地 震の最終すべり分布の比較. 
傍のすべり量が大きい領域の北側にもすべり量が大きい 領域が得られている等, 共通した結果が得られている.

久保らの破壊のスナップショットでは破壊開始点から 始まった震源の破壊が北側に進行寸る様子が見られ，こ の結果は図-3に示寸震源近傍域における観測記録と整合 している.

\section{5. 震源のモデル化}

\section{(1) 概要}

2016年鳥取県中部の地震に対して釜江・入倉のモデル 化手法9に従い，経験的グリーン関数法 ${ }^{8}$ によるフォワー ドモデリング手法を用い震源のモデル化を行う。この方 法は，波形インバージョン結果を参考に断層面上の寸べ り量の大きい場所に強震動生成域 (Strong Motion Generation Area，以下，SMGA）を配置し，合成地震動と観測 地震動との一致度からSMGAの数量, 位置, サイズ, 応 力降下量などのパラメータを定量化するものである.

SMGAの形状を矩形とし，すべり量も均一な単純なモデ ル化ながら，M7クラスの国内外で発生した内陸地殼内 地震の不均一震源モデルに適用され，有効性が確認され

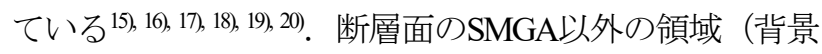
領域）からも地震動を生成するが，震源近傍域の強震動 への寄与度が低いことから ${ }^{19}$ ，強震動はSMGAのみから 生成されると考え背景領域は考慮しない. フォワードモ デリング手法の詳細は参考文献9,15,10,177,18, 19,200を参照され たい.

合成地震動との比較にはKiK-net溝口（TTRH03）， KiK-net河原（TTRH06），KiK-net関金（TTRH07)，KiK-net 勝央（OKYH11），K-NET倉吉（TTR005），K-NET上斎 原（OKY015）の6地点の観測記録を使用した. KiK-netの 観測記録は地盤の非線形特性の影響を受けにくい地中観 測記録とした。

K-NETの観測記録は地表に地震計が設置されているた め, 強震時に表層地盤の非線形特性を含むサイト特性の 影響を受けやすい． 経験的グリーン関数法は地盤の非線 形特性を直接考慮できないことから，合成地震動は観測 地震動に比心゙振幅を大きめに評価し，かつ短周期成分が 卓越することが知られている ${ }^{19}$. そのため, K-NETの観 測地点を対象に強震動評価を行う際にはこれらの影響を 考慮する必要があるが，本検討ではTTR005とOKY015の 観測記録は震源ごく近傍地点の強震動の継続時間の評価 を目的とするため，非線形を含むサイト特性の考慮は行 わない. 図-2に各観測地点の位置を示寸.

\section{(2) 断層面の設定}

震源破壊過程を引用した久保ら，小林らの研究ではF-

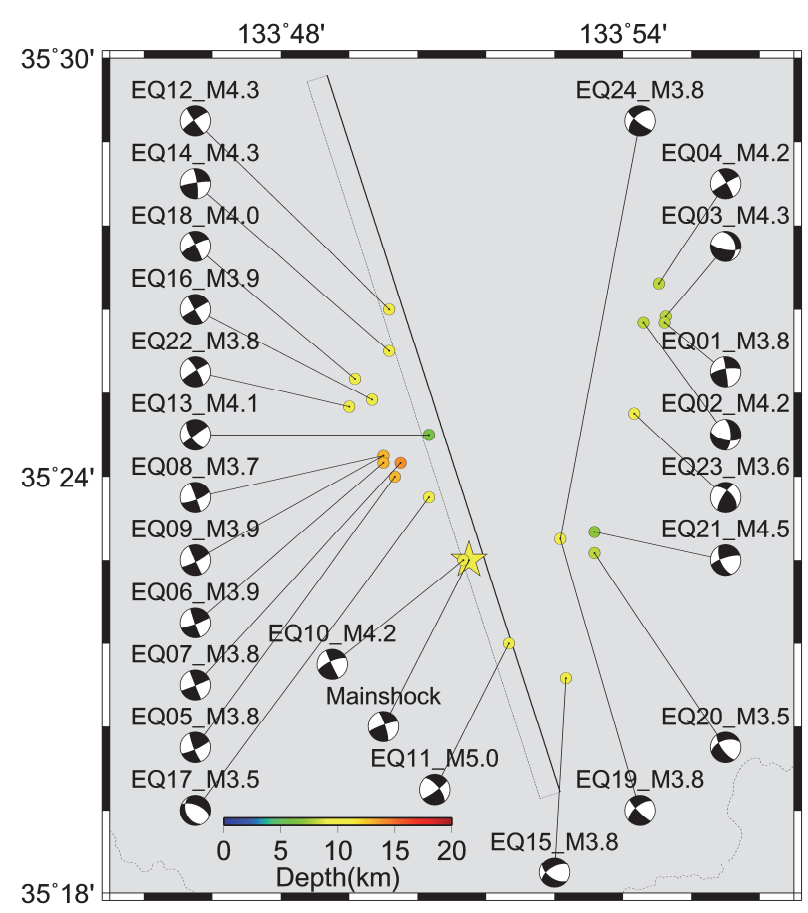

図-5 2016年鳥取県中部の地震の震源近傍で発生した地震の うち, F-netのメカニズム解が得られている地震の震源 分布

netのメカニズム解（暫定值）を参考に走向162度，傾斜 88度の西傾斜の断層面を設定している. 本検討でも余震 の震源分布を検討し，同様の断層面を設定した．具体的 には，断層面基準点が35.4959N，133.8135E，走向162度， 傾斜88度の西傾斜の断層面を設定した. 図-2に設定した 想定断層面を示寸．断層面のサイズは $20 \mathrm{~km} \times 15 \mathrm{~km}$ とし ているが，本検討では背景領域からの地震動生成を考慮 していないため, 断層面の大きさは震源のモデル化に影 響を与えない.

\section{(3) 経験的グリーン関数イベントに用いる小地震の選 定と震源パラメータの設定}

経験的グリーン関数法は，地震動を予測する大地震と 経験的グリーン関数イベントとして用いる小地震の地震 の相似則と震源スペクトルの相似則に基づき，大地震の 地震動を経験的グリーン関数の線形な重㸚合わせで表現 する．そのため，経験的グリーン関数法の精度は経験的 グリーン関数イベントとして用いる小地震の選定，およ び小地震の震源パラメータの設定精度にも大きく依存す る.

図-5に想定断層面が含まれる北緯35度18分〜35度30分， 東経133度48分〜133度57.5分の範囲に震央を有した地震 のうち，マグニチュードがMj3.5〜Mj4.5の範囲にあり， 合成地震動との比較に用いる6地点での地震動記録およ びF-netのメカニズム解が得られている24地震の震源分布 を示す. 図-5に示すようにEQ10は本地震の破壊開始点 
とほぼ同じ位置に震央を有し，震源深さもほぼ同じであ る.そのためEQ10の地震動を経験的グリーン関数イベ ントとして使用する. 以降, EQ10を要素地震と呼ぶ.

表-2に要素地震の諸元を示す，要素地震は本地震が発生 する直前に発生した地震であり，メカニズム解もほぼ同 じである。

要素地震の震源パラメータとして面積および応力降下 量を設定する．二つのパラメータは要素地震のコーナー

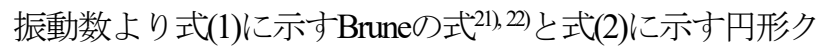
ラックの式23)からそれぞれ評価する.

$$
\begin{aligned}
& r_{a}=\frac{2.34 \cdot \beta}{2 \cdot \pi \cdot f_{c a}} \\
& \Delta \sigma_{a}=\frac{7}{16} \frac{M_{0 a}{ }^{2}}{r_{a}^{3}}
\end{aligned}
$$

raは要素地震を円形とみなした場合の見かけの半径 $(\mathrm{km}), f_{c}$ は要素地震のコーナ一振動数 $(\mathrm{Hz}), \quad \beta$ は当該地点 の岩盤のせん断波速度 $(\mathrm{km} / \mathrm{s}), \Delta \sigma_{a}$ とM0aは要素地震の忘 力降下量 $(\mathrm{MPa})$ と地震モーメント $(\mathrm{N} \cdot \mathrm{m})$ である. 本検討で は $\beta=3.5 \mathrm{~km} / \mathrm{s}$ した.

要素地震のコーナー振動数は三宅ら ${ }^{24)}$ にる Source Spectral Ratio Fitting Method（以下，SSRF法）から評価する. SSRF法の詳細は原著 ${ }^{24}$ に譲りここでは具体的な取り扱い 方法を中心に説明する. SSRF法は同一地点で観測され た大地震動と小地震動の観測震源スペクトル比にBrune の $\omega^{-2}$ スペクトルに基づく大地震と小地震の震源スペク

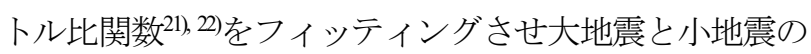
モーメント比, および大地震と小地震のコーナ一振動数 を求め, そこから波形合成の重ね合わせ数 $N$ と大地震と 小地震の応力降下量の比Cを評価する方法である. 式(3) に震源スペクトル比関数を示す.

$$
\operatorname{SSRF}(f)=\frac{M_{0 M}}{M_{0 m}} \frac{1+\left(\frac{f}{f_{c m}}\right)^{2}}{1+\left(\frac{f}{f_{c M}}\right)^{2}}
$$

$\operatorname{SSRF}(f)$ が震源スペクトル比関数，MomとMomは大地震 と小地震の地震モーメント， $f_{\mathrm{cm}}$ と $f_{\mathrm{cm}}$ は大地震と小地震の コーナ一振動数である.

震源スペクトル比関数のフィッティング手順は次の通 りである．まず，複数の観測地点を対象に観測震源スペ クトル比を求める．次にフィッティング対象とする振動 数範囲をM分割し， 中心振動数が $f_{i}(i=1 \sim \mathrm{M})$ で幅 $2 \mathrm{a}_{i}$ の 振動数帯ごとに全観測地点を対象としたM個の観測震源

\begin{tabular}{cc} 
表-2 & 経験的グリーン関数イベントとして用いる地震の諸元 \\
\hline 発生日時 & 2016 年10月21日12時12分23.02秒 \\
\hline 震央 & $35^{\circ} 22.84{ }^{\prime} \mathrm{N} 133^{\circ} 51.29^{\prime} \mathrm{E}$ \\
\hline 深さ & $10.26 \mathrm{~km}$ \\
\hline マグニチュード & $M \mathrm{j} 4.2, M \mathrm{w} 4.1^{10)}$ \\
\hline 地震モーメント ${ }^{10)}$ & $1.81 \times 10^{15} \mathrm{~N} \cdot \mathrm{m}$ \\
\hline STR/DIP/RAK ${ }^{10)}$ & $246 ; 155 / 72 ; 87 /-177 ;-18$ \\
\hline コーナー振動数 & $1.87 \mathrm{~Hz}$ \\
\hline 応力降下量 & $2.34 \mathrm{MPa}$ \\
\hline 面積 & $1.44 \mathrm{~km}$
\end{tabular}

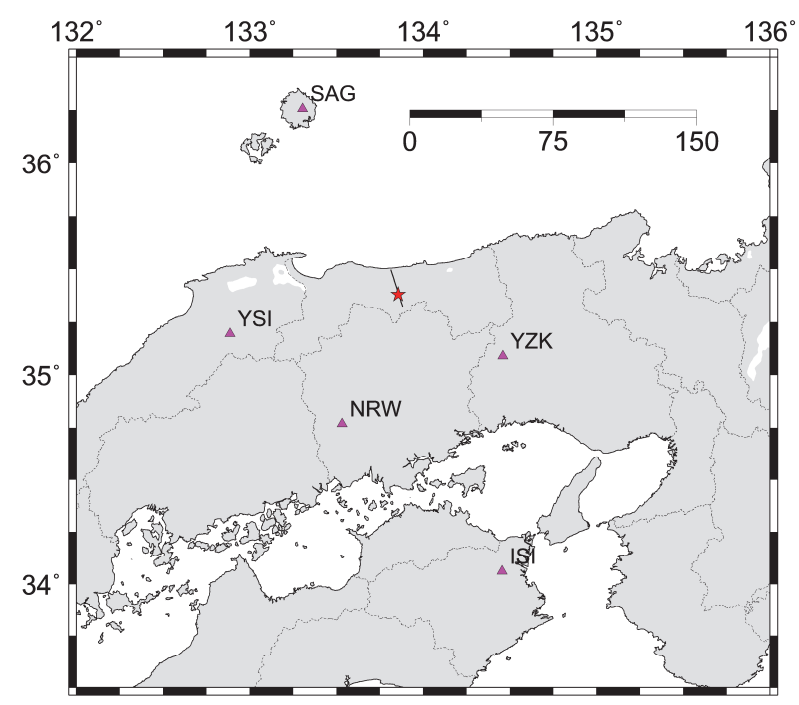

図-6 要素地震のパラメータ評価に用いる観測震源スペクト ル比を求める広帯域地震計の地震観測地点

スペクトル比の対数平均值 $\log (O S R(f)$, ) と対数標準偏差 $\log (S . D .(f), i)$ を求める. aは定数で本検討では $=0.5$ とした. このM個の観測震源スペクトル比を目標として式(3)に示 す震源スペクトル比関数をフィッティングさせる. 具体 的には式(4)で示される重みつき残差二乗和Rが最小とな るように $f_{\mathrm{c} M}$ と $f_{\mathrm{cm}}$ をパラメータとしたグリッドサーチを行 う。 小地震の長周期成分を高精度に計測することが難し いため，本検討では式(3)のMom/Momはパラメータとせず 大地震と小地震の地震モーメントの比で拘束する.

$$
R=\sum_{i=1}^{M}\left(\frac{\log \left(\operatorname{SSRF}\left(f_{i}\right)\right)-\log \left(\operatorname{OSR}(f)_{, i}\right)}{\log \left(S \cdot D \cdot(f)_{, i}\right)}\right)^{2}=\min
$$

本検討では大地震に本地震を, 小地震に要素地震を適 用し，要素地震のコーナ一振動数を評価する．観測地震 動は長周期側の精度を確保するため広帯域地震計STS-2 で得られた3成分の速度波形とし3)，震源を囲むように SAG（西郷），YSI（吉田），NRW（成羽），YZK（山 崎），ISI（徳島）の5地点を選定した。図-6に各観測地 


\section{点の位置を示す.}

時間領域の解析区間はS波部分とし，観測震源スペク トル比を計算する前に中心振動数の $20 \%$ の幅の平滑化を 行った。伝播経路の補正は幾何減衰と媒質のQ值 $\left(Q(f)=131 f^{0.68}\right)^{25)}$ による減衰を考慮した。観測震源スペ クトル比と震源スペクトル比関数のフィッティング範囲 は $0.1 \mathrm{~Hz} \sim 10.0 \mathrm{~Hz}$ と，分割数はM=11とした.

図-7に震源スペクトル比関数のフィッティング結果を 示す. 要素地震のコーナ一振動数は $1.87 \mathrm{~Hz}$ と評価された. 表-2にコーナ一振動数から算出した要素地震の面積と応 力降下量を示す.

大地震と小地震の震源が近い場合，使用するQ值特性 が観測震源スペクトル比に及ぼす影響は小さいと考えら れる. 確認のため別の研究から得られた 3 種類のQ值特

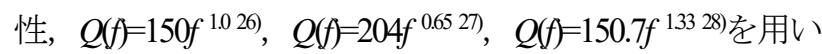
た場合のフィッティング結果を図-8に示す。本検討で用 いたQ值特性を含め，震源スペクトル比関数は同じ結果 となり，Q值特性による影響が小さいことが確認された。

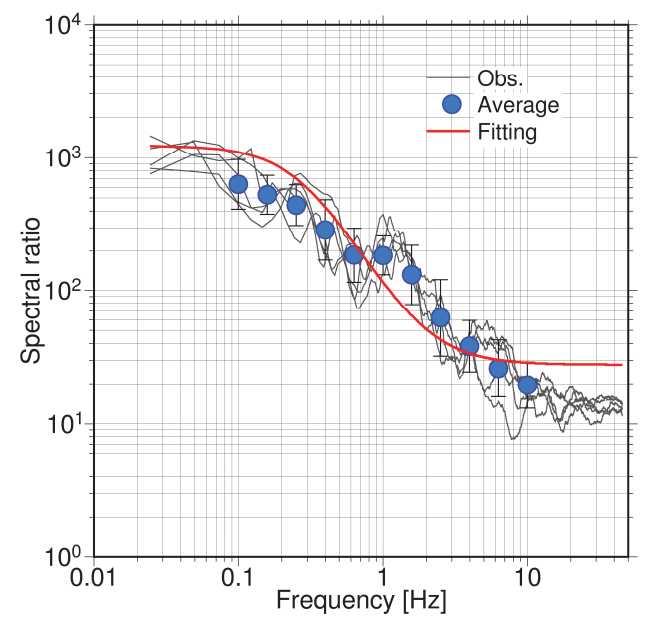

図-7 観測震源スペクトル比と震源スペクトル比関数とのフィ ッティング状況

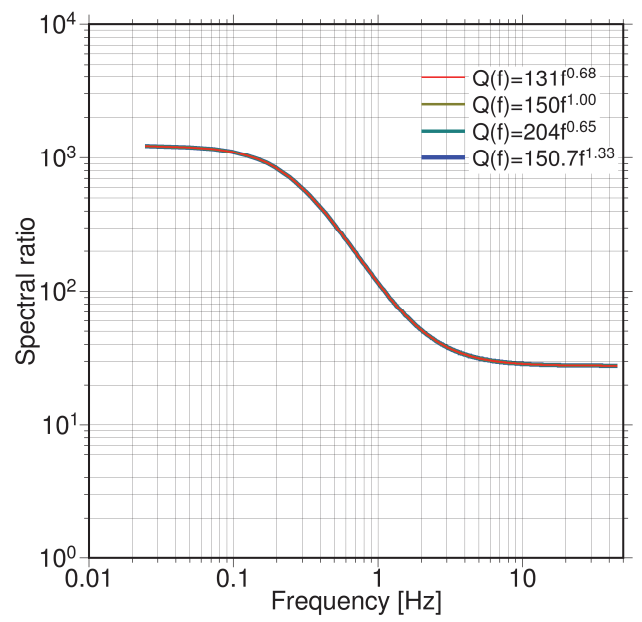

図-8＼cjkstart震源スペクトル比関数に及ぼすQ值特性の影響
観測震源スペクトル比と震源スペクトル比関数のフィ ッティング範囲は観測震源スペクトル比の有効振動数帯 域を考慮して設定した。本検討では広带域地震計STS-2 で観測された地震動を使用しており，その有効振動数帯 が $0.01 \mathrm{~Hz} \sim 10 \mathrm{~Hz}$ であることから，フィッティングの上限 振動数を $10 \mathrm{~Hz}$ とた。 また，高域遮断振動数 $f_{\text {max }}{ }^{29}$ を考慮 した場合，観測震源スペクトル比は大地震の $f_{\text {max }}$ よりも やや低い振動数から低下し始めるため， $f_{\max }$ の影響が小 さい振動数領域でフィッティングを行う必要がある. 本 地震の $f_{\max }$ は明らかにされていないが，ほぼ同じ規模の 2016年熊本地震の最大前震（Mj6.5）の $f_{\max }$ が9.9Hzである ことから ${ }^{30)}$, 本検討におけるフィッティングの上限振動 数は妥当と考えられる. なお，高振動数側の有効振動数 を $10 \mathrm{~Hz} よ り$ 高くした場合, 高振動数帯域の一致度は向 上するが，低振動数側の一致度が低下し，式(4)で示さ れる重みつき残差二乗和Rの值は $10 \mathrm{~Hz}$ の場合よりも大き くなる. フィッティングの下限振動数は地震動のS/N比 および震源変位スペクトルのフラットレベルの振動数範 囲から0.1Hzとした。

\section{(4) 震源のモデル化}

波形インバージョンの結果を参考に，震源周辺のす心゙ り量の大きい場所にSMGAを配置した初期モデルを作成 し，経験的グリーン関数法による合成地震動と観測地震 動との一致度を目視で判断しSMGAの数, 位置, 大きさ, 破壊開始点を変更する。目視による判断では震源近傍の TTRH07の観測波形の再現とTTR005とOKY015の継続時 間の再現を優先したモデルの変更を行い，最終的には式 (5)に示す評価関数を用いてRが最小になるモデルを最適 解とする. stationは観測波形と合成波形の一致度を評価 する観測地点数でTTRH07を含めたKiK-netの4地点である. compは地震動の成分数で水平 2 成分と鉛直成分の 3 成分と した。 Obsは観測時刻歴波形，Synは合成時刻歴波形， $t$ は時刻を示す。本検討では時刻歴波形には1.0Hzのロー パスフィルターを作用させた変位波形を使用した。

$$
R=\sum_{\text {station comp }} \sum_{\left\{\sum_{t} O b s^{2} \cdot \sum_{t} S y n^{2}\right\}^{0.5}}^{\sum_{t}(O b s-S y n)^{2}}
$$

図-9に設定した震源モデルを示すＳMGAは震源の周 辺とその北側に2つ設置した。波形インバージョンでは 震源の周辺に大きなすべり量が見られたため，初期モデ ルとして1つのSMGAを震源の周辺に設置し良い結果を 得た。しかし，震源に最も近いTTR005では主要動の前 半部しか波形が再現できなかったため，震源北側に見ら れたすべり量の大きい範囲に小さいSMGAを追加配置し 
た. 震源近傍のSMGAをSMGA1，震源北側のSMGAを SMGA2とする.SMGAの破壊はSMGA1の下方の破壊開 始点から同心円状に伝播し，破壊がSMGA2に達した際 に再びSMGA2が同心円状に破壊するとした．表-3に強 震動生成域の諸元を示す.

図-10に前述の6地点における観測地震動と経験的グリ ーン関数法加評価した合成地震動（加速度波形，速度 波形，変位波形）の比較（NS成分）を示寸．また，図11に擬似速度応答スペクトル $(h=0.05$, 以下，応答スペ クトル）と加速度フーリエスペクトル（以下，フーリエ スペクトル）を比較して示寸．波形合成における有效振 動数帯は要素地震のS $/ \mathrm{N}$ 比や変位スペクトルのフラット レベルを検討し $0.2 \mathrm{~Hz} \sim 10 \mathrm{~Hz}$ （0.1秒〜 5秒） とした.

震源に最も近いTTRH07では観測地震動に見られるパ ルス状の波形が再現できている．特に速度波形と変位波 形の一致度は高い.このパルス状の波形はSMGA2を考 慮しなくとも再現できるため, 震源周辺の大きなすべり 領域から生成された地震動によるものと考えられる.

TTRH03 とTTRH06は震源から西側と東側に約 $30 \mathrm{~km}$ 離孔 ている観測地点である. 破壊開始点から $30 \mathrm{~km}$ 以上離れ ているためTTRH07で見られたようなパルス状の波形は 見られないが主要動の継続時間や速度波形に見られる周

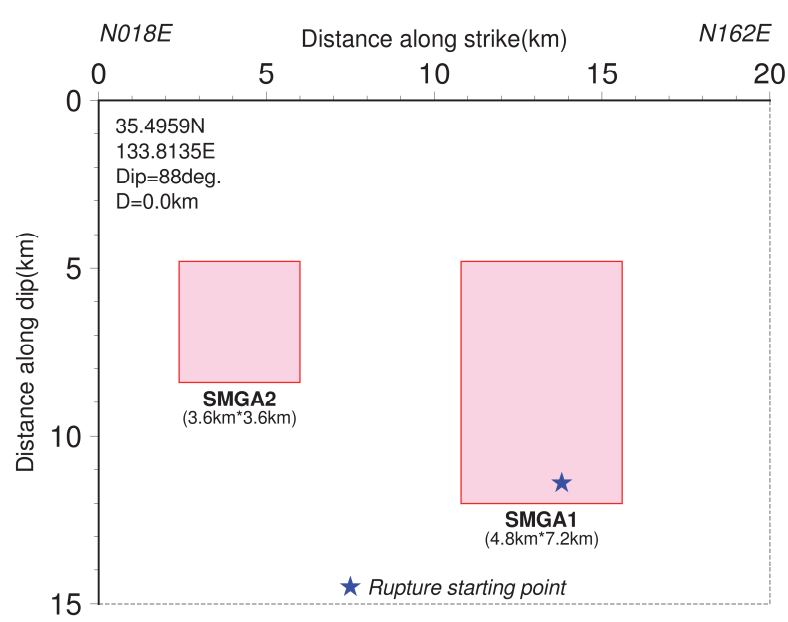

図-9 経験的グリーン関数法を用いたフォワードモデリング により評価した震源モデル

表-3 震源モデルの強震動生成域の諸元

\begin{tabular}{cccc}
\hline & & SMGA1 & SMGA2 \\
\hline \hline 面積 & $\mathrm{km}^{2}$ & $\begin{array}{c}34.56 \\
(4.8 \mathrm{~km} \times 7.2 \mathrm{~km})\end{array}$ & $\begin{array}{c}12.96 \\
(3.6 \mathrm{~km} \times 3.6 \mathrm{~km})\end{array}$ \\
\hline 重ね合わせ数 & & $4 \times 6 \times 4.9$ & $3 \times 3 \times 3.0$ \\
\hline 地震モーメント & $\mathrm{N} \cdot \mathrm{m}$ & $1.06 \times 10^{18}$ & $2.44 \times 10^{17}$ \\
\hline 上端深さ & $\mathrm{km}$ & 4.8 & 4.8 \\
\hline 応力降下量 & $\mathrm{MPa}$ & 11.70 & 11.70 \\
\hline 破壊伝播速度 & $\mathrm{km} / \mathrm{s}$ & 2.7 & 2.7 \\
\hline ライズタイム & $\mathrm{s}$ & 0.40 & 0.24 \\
\hline
\end{tabular}

期1秒程度の波形は再現できている．また，バックワー ド側の観測地点と考えられるOKYH11では加速度波形の 継続時間をほぼ再現できている．震源近傍および比較的 近いTTRH07およびOKYH11の応答スペクトルとフーリ エスペクトルの一致度は高い. 一方, TTRH03, TTRH06 では若干小さめの評価となっている. 本検討では震源近 傍のTTRH07の観測波形の一致度の向上を優先している こと，使用した経験的グリーン関数法では距離によらず 同じ距離减衰特性（1/距離）を用いており距離が遠くな ると大きめの減衰特性を与えること等が理由として考え られる. EW成分およびUD成分の観測結果と合成結果と の一致度についてはNS成分と同様の傾向である.

TTR005, OKY015は前述の理由から合成加速度波形の 振幅は観測加速度波形の振幅に対して大きめの評価にな っており，合成地震動のスペクトル特性も観測地震動に 比べると短周期成分が卓越する. 一方, 主要動の継続時 間は再現できている。震源に最も近いTTR005では SMGA2を考慮しない場合, 合成波形の主要動の継続時 間は3秒程度であり，震源ごく近傍の地震動を再現する ためにはSMGA2が必要であると考えられる.

本検討で構築した震源モデルの震源パラメータを震源 断層を特定した強震動予測手法（以下，レシピ） に基 づく推定值と比較する. 比較する震源パラメータは, 地 震モーメント, ライズタイム, 加速度震源スペクトルの レベル（以下，短周期レベル）である，なお，レシピに おけるアスペリティとSMGAは等価とする.

アスペリティの面積を震源断層全体の $1 / 4$ ，アスペリ ティの平均すべり量が震源断層全体の平均すべり量の 2 倍とすると, 震源断層全体に対するアスペリティの地震 モーメントの割合は $50 \%$ となる. 一方, 構築した震源モ デルのSMGAの地震モーメントの総和は全体の $58 \%$ とな り, 地震モーメントの割合は本モデルの方がやや大きめ である.

レシピではライズタイムtは式(6)で評価される.

$$
t_{r}=\frac{\alpha \cdot W}{V_{r}}
$$

WはSMGAの幅（km），Vｒは破壊伝播速度（km/s）， $\alpha$ は係数で 0.5 とされている. 式(6)に従いSMGAのライズ タイムを評価すると, SMGA1が0.89秒, SMGA2が0.67秒 となり本モデルよりも長めとなる．ただし式(6)中のaに は幅があることが知られており, 本モデルのライズタイ ムから $\alpha$ を逆残すると 0.225 と0.18となり, 片岡ら ${ }^{31}$ の研究 $(\alpha=0.2 \sim 0.4)$ の下限に近い值となる.

レシピでは短周期レベルは式(5)に示寸壇ら ${ }^{32)}$ のスケー リング則により地震モーメントから式(7)で評価する. 
土木学会論文集A1 構造 地震工学), Vol. 74, No. 4 她震工学論文集第37巻), I_497-I_507, 2018.
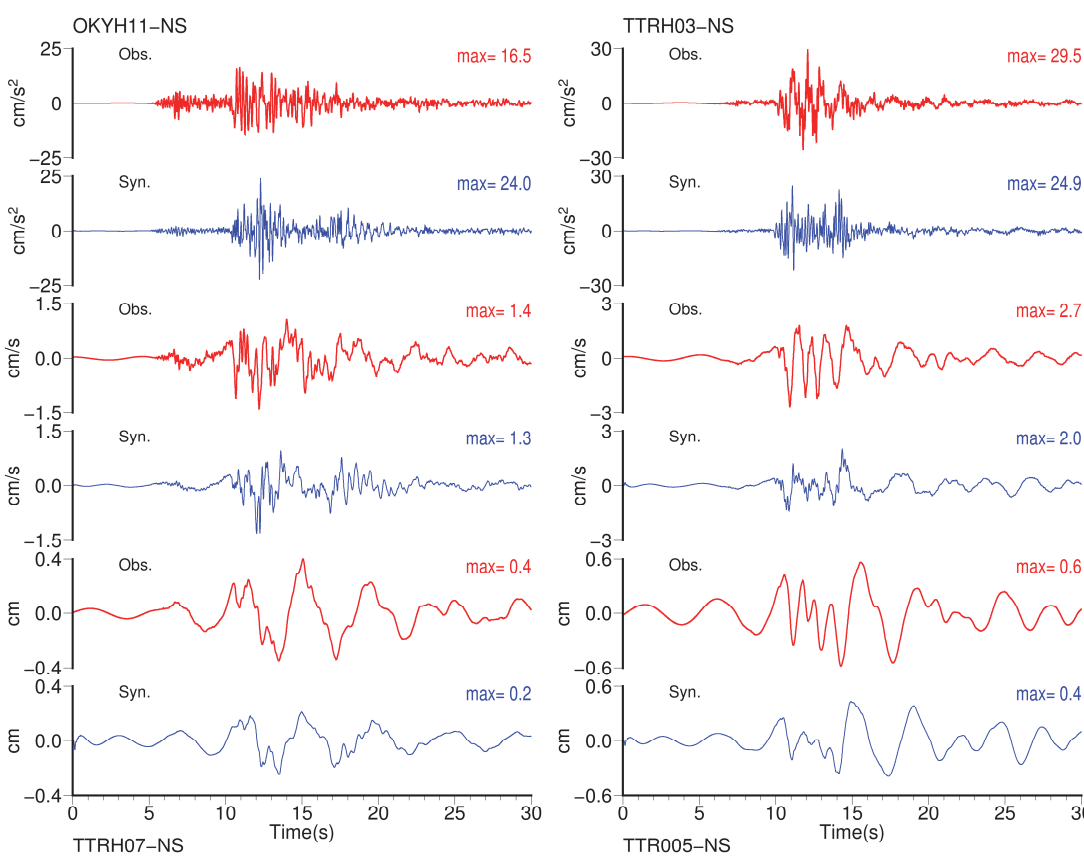

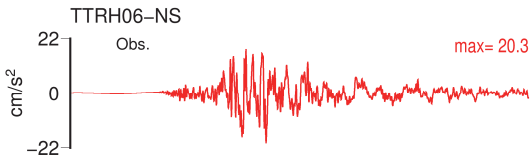

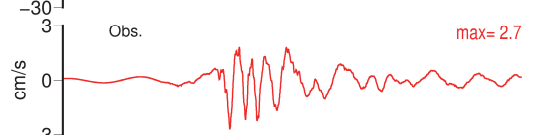

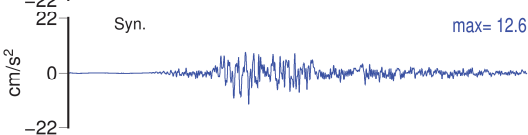
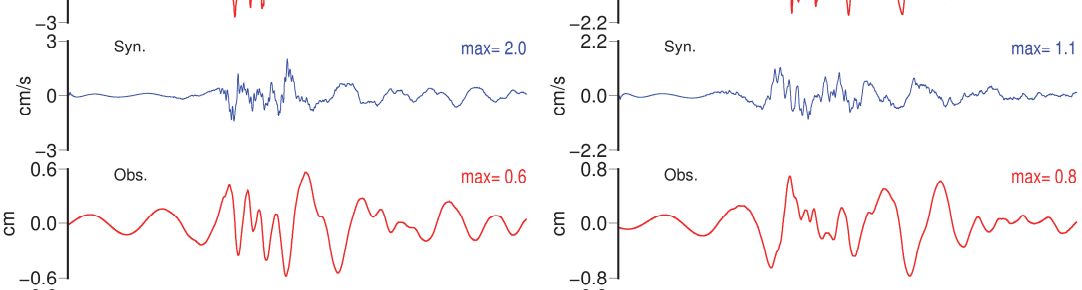

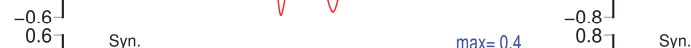

$\max =0.4$
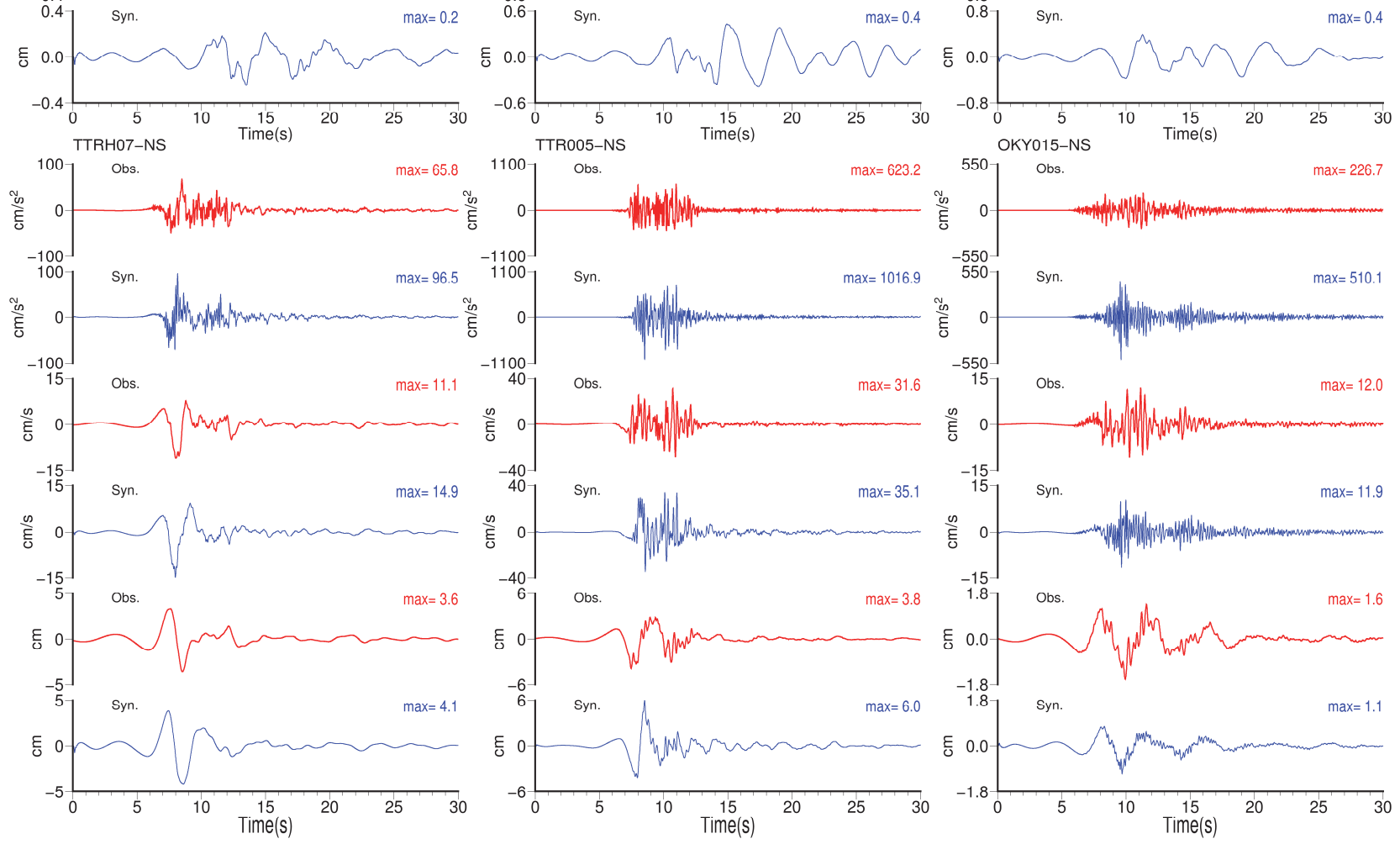

図-10 観測地震動と合成地震動の時刻歷波形の比較（赤線 : 観測，青線 : 合成）
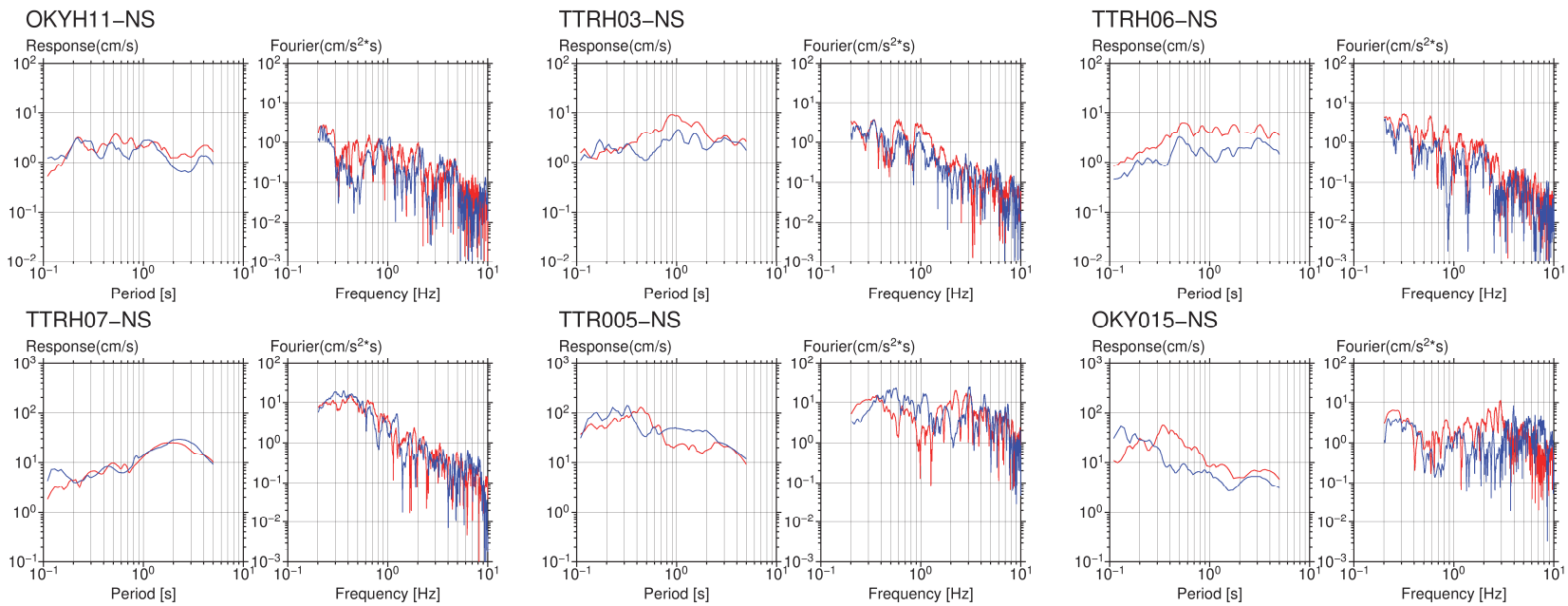

図-11 観測地震動と合成地震動の擬似速度応答スペクトル $(h=0.05)$ と加速度フーリエスペクトルの比較（赤線 : 観測，青線 : 合 成) 


$$
A=2.46 \times 10^{10} \times\left(M_{0} \times 10^{7}\right)^{1 / 3}
$$

Aは短周期レベル $\left(\mathrm{N} \cdot \mathrm{m} / \mathrm{s}^{2}\right) ， M_{0}$ は地震モーメント $(\mathrm{N} \cdot \mathrm{m})$ を示す。図-12にスケーリング則を示す。図中 の細い破線はスケーリング則の0.5倍と2.0倍を示す．構 築した震源モデルの短周期レベルは式(8) ${ }^{33)}$ より算出でき る.

$$
A=4 \pi \cdot r_{S M G A} \cdot \Delta \sigma_{S M G A} \cdot \beta^{2}
$$

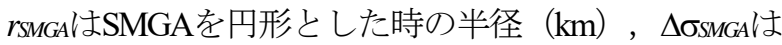
SMGAの応力降下量（MPa）， $\beta$ は震源域における岩盤 のS波速度である. 図-12に式(8)から得られた短周期レベ ルと地震モーメントの関係を赤色のれ印で示す. 図中に は参考として他の内陸地殼内地震のフォワードモデリン グから算出された短周期レベル15), 16, 17), 18), 19, 20), 32), 33)を併せ て示す. 図からわかるように本検討で構築した震源モデ ルの短周期レベルは既往のスケーリング則 32 で表現でき ている。

\section{6. まとめ}

2016年鳥取県中部の地震（Mj6.6）を対象に震源近傍 を含む周辺域で観測された地震動記録を用い，当該地震 の震源モデルを経験的グリーン関数法を用いたフォワー ドモデリングにより評価し，破壊開始点周辺に大きい SMGAとその北側に小さいSMGAを有する震源モデルを 構築した.

震源モデルは，震源近傍の強震動ならびに震源放射特 性とともに破壊の指向性によると考えられる “パルス 波”を再現することができた。 また，観測地震動は破壊

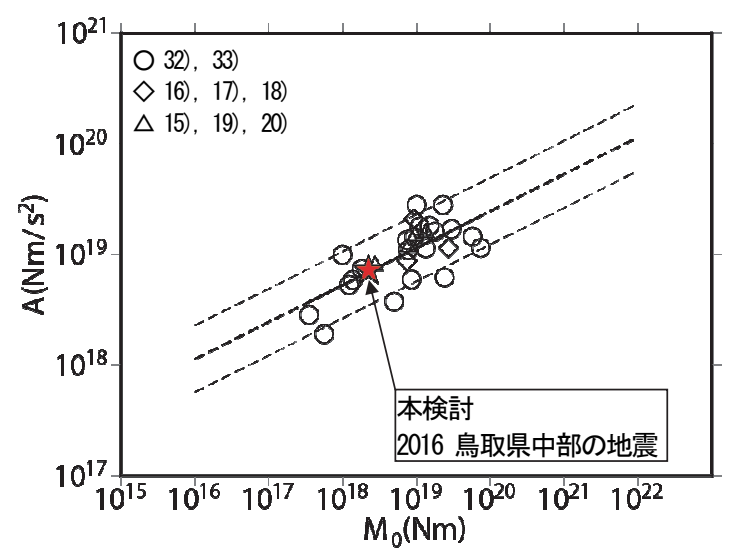

図-12 地震モーメント $\left(M_{0}\right)$ と加速度震源スペクトルの短周 期レベル (A) との関係
開始点周辺の大きなSMGAから生成された地震動が支配 的であることが分かった.

本地震の地震モーメントと加速度震源スペクトルの短 周期レベルの関係は既往のスケーリング則で表現できる ことがわかった。

謝辞 : 本研究では防災科学技術研究所の強震観測網KNETおよびKiK-netの地震動記録と関連データ，気象庁な らびに鳥取県, 岡山県の地震動記録，F-netのメカニズム 解, 気象庁の震源データを使用させていただきました. 作図においては国土地理院の電子地形図・電子国土web を使用させていただきました，本研究は科研費基盤研究 (C)15K06204（研究代表者：池田隆明），平成28年度原 子力施設等防災対策等委託費（地震動評価における不確 かさの評価手法の検討）業務および平成29年度原子力施 設等防災対策等委託費（内陸型地震による地震動評価手 法の検討）業務による成果の一部として実施いたしまし た. 最後に記して謝意を表します.

\section{参考文献}

1) 鳥取県: 平成 28 年 10 月 21 日鳥取県中部地震につい て，第 96 報，http://www.pref.tottori.lg.jp/261100.htm (2017.08.21 閲覧)

2) 防災科学技術研究所 : 広帯域地震観測網, F-net, http://www.fnet.bosai.go.jp（2017.08.23 閲覧）

3) 防災科学技術研究所 : 高感度地震観測網, Hi-net, http://www.hinet.bosai.go.jp/（2017.08.23 閲覧）

4) 国土地理院: 平成 28 年鳥取県中部の地震に関する情 報, だいち 2 号干渉 SAR による変動の検出について, http://www.gsi.go.jp/BOUSAI/H28-tottori-earthquakeindex.html（2017.08.23 閲覧）

5) 京都大学防災研究所鳥取微小地震観測所, 鳥取大学 教養部地学教室 : 1983 年 10 月 31 日鳥取県中部の地 震（M6.2）について, 地震予知連絡会, 会報第 31 巻, 6-4, pp.390-398, 1984.

6) 地震調査研究推進本部: 震源断層を特定した地震の 強震動予測手法（「レシピ」），

http://www.jishin.go.jp/evaluation/strong_motion/ (2017.08.23 閲覧)

7) 加藤研一, 宮腰勝義, 武村雅之, 井上大榮, 上田圭 一，壇一男：震源を事前に特定できない内陸地殼内 地震による地震動レベルー地質学的調査による地震 の分類と強震観測記録に基づく上限レベルの検討一, 日本地震工学会論文集, Vol. 4, No. 4, pp.46-86, 2004.

8) Irikura, K.: Prediction of strong acceleration motion using empirical Green's function, Proceedings of the 7th Japan Earthquake Engineering Symposium, pp.151-156, 1986.

9) 釜江克宏, 入倉孝次郎：1995 年兵庫県南部地震の断 層モデルと震源近傍における強震動シミュレーショ ン, 日本建築学会構造系論文集, No.500, pp.29-36, 1997.

10) 防災科学技術研究所：強震観測網（K-NET, KiKnet) , http://www.kyoshin.bosai.go.jp/kyoshin/ 
(2017.08.23 閲覧)．

11) 気象庁: 強震波形（鳥取県中部の地震）, http://www.data.jma.go.jp/svd/eqev/data/kyoshin/jishin/16 10211407_tottoriken-chubu/index.html （2017.08.23 閲覧）

12) 気象庁：地方公共団体震度計の波形データ， http://www.data.jma.go.jp/svd/eqev/data/kyoshin/jishin/16 10211407_tottoriken-chubu/index2.html（2017.08.23 閲 覧)

13）久保久彦, 鈴木亘, 青井真, 関口春子 : 近地強震記 録を用いた 2016 年 10 月 21 日 鳥取県中部で発生した 地震の震源インバージョン解析,

http://www.kyoshin.bosai.go.jp/kyoshin/topics/Tottori_201 61021/inversion/inv_index.html（2017.08.23 閲覧）

14) 小林広明, 纐纐一起, 三宅弘恵 : 強震波形インバー ジョンによる 2016 年鳥取県中部の地震の震源過程 （暫定版），

http://taro.eri.u-tokyo.ac.jp/saigai/2016tottori/index.html (2017.08.23 閲覧)

15）池田隆明, 釜江克宏, 三輪 滋, 入倉孝次郎 : 経験 的グリーン関数法を用いた 2000 年鳥取県西部地震の 震源のモデル化と強震動シミュレーション, 日本建 築学会構造系論文集, No. 561, pp.37-45, 2002.

16) Kamae, K., Ikeda, T, and Miwa, S.: Source model composed of asperities for the 2004 Mid Niigata Prefecture, Japan, earthquake ( $\left.\mathrm{MJMA}_{\mathrm{JM}}=6.8\right)$ by the forward modeling using the empirical Green's function method, Earth Planets Space, Vol.57, pp.533-538, 2005.

17) 釜江克宏, 川辺秀憲: 2007 年新潟県中越沖地震 (Mj6.8)の震源のモデル化と強震動シミュレーション, http://www.rri.kyoto-u.ac.jp/jishin/kenkyunaiyou.html （2017.08.23 閲覧）

18) 釜江克宏 : 2008 年岩手・宮城内陸地震(Mj7.2)の震源 のモデル化（暫定版），

http://www.rri.kyoto-u.ac.jp/jishin/kenkyunaiyou.html (2017.08.23 閲覧)

19）池田隆明, 釜江克宏, 入倉孝次郎：経験的グリーン 関数法を用いた震源のモデル化と地盤の非線形性を 考慮した地震動評価, 2005 年福岡県西方沖の地震と 2007 年能登半島地震への適用, 日本建築学会構造系 論文集，No.665, pp.1253-1261，2011.

20) 池田隆明, 小長井一男, 釜江克宏, 佐藤京, 高瀬裕 也：2014 年長野県北部の地震の被害調査と震源のモ デル化, 土木学会論文集 A1（構造地震工学）, Vol.72, No.4, pp.I_975-I_983, 2016.

21) Brune, J. N.: Tectonic stress and the spectra of seismic shear waves from earthquakes, Journal of Geophysical Research, Vol.75, pp.4997-5009, 1970.

22) Brune, J. N.: Correction, Journal of Geophysical Research, Vol.76, p.5002, 1971.

23) Eshelby, J. D.: The determination of the elastic field of an ellipsoidal inclusion, and related problems, Proceedings of the Royal Society of London. Series A, Mathematical and Physical Sciences, Vol.241, Issue 1226, pp.376-396, 1957.

24) 三宅弘恵, 岩田知孝, 入倉孝次郎：経験的グリーン 関数法を用いた 1997 年 3 月 26 日（MJMA6.5）及び 5 月 13 日 $\left(\mathrm{M}_{\mathrm{JMA}} 6.3\right)$ 鹿児島県北西部地震の強震動シ ミュレーションと震源モデル, 地震, 第 2 輯, Vol.51, No.4, pp.431-442, 1999.

25) 佐藤智美 : KiK-net 強震記録に基づく鳥取県西部地震 とその余震のラディエーションパターン及び $f_{\max }$ の評 価, 日本建築学会構造系論文集, No.556, pp.25-34, 2002.

26) 川瀬 博, 松島信一, 佐藤智美, 伏見 実, 巽 誉 樹：JMA87 型強震計の観測記録に基づいた震源・伝 播経路・サイトの各特性の分離, （その1）内陸浅発 地震の場合, 日本建築学会大会学術講演梗概集（中 国），B-2，pp.201-202， 1999.

27) 川瀬 博, 松尾秀典 : K-NET, KiK-net, JMA 震度計 観測網による強震動波形を用いた震源・パス・サイ 卜各特性の分離解析, 日本地震工学会論文集, Vol.4, No.1, pp.33-52, 2004.

28) Nakano, K., Matsushima, S. and Kawase, H.: Statistical properties of strong ground motions from the generalized spectral inversion of data observed by K-NET, KiK-net, and the JMA Shindokei Network in Japan, Bulletin of the Seismological Society of America, pp.2662-2680, 2015.

29) 鶴来雅人, 香川敬生, 岡崎敦, 羽田浩二, 入倉孝次 郎：強震動予測のための高域遮断フィルターに関す る研究 -1995 年兵庫県南部地震の観測記録に基づく 検討一, 日本地震工学会論文集, Vol.6, No.4, pp.94$112,2006$.

30) 鶴来雅人, 田中礼司, 香川敬生, 入倉孝次郎：強震 動予測のための高域遮断フィルターに関する研究 (そ の 3)一国内で発生した地殼内地震の観測記録に基づ <検討一, 日本地震工学会論文集, Vol.17, No.5, pp.109-132, 2017.

31) 片岡正次郎, 日下部毅明, 村越潤, 田村敬一：想定 地震に基づくレベル 2 地震動の設定手法に関する研 究, 国土技術政策総合研究所研究報告, 第 15 号, 2003.

32）壇一男, 渡辺基史, 佐藤俊明, 石井透: 断層の非一 様すべり破壊モデルから算定される短周期レベルと 半経験的波形合成法による強震動予測のための震源 断層のモデル化, 日本建築学会構造系論文集, No.545, pp.51-62, 2001.

33）壇一男, 武藤真菜美, 石井やよい, 阿比留哲生 : 内 陸地震の断層タイプ別にみた各種マグニチュードの 関係とそれに基づく断層モデルの設定と強震動の試 算, 日本建築学会構造系論文集, Vol.75, No.650, pp.741-750, 2010.

(2017.11.3 受付, 2018.2.16 修正, 2018.2.17 受理) 


\section{SOURCE CHARACTERIZATION \\ OF THE 2016 CENTRAL TOTTORI PREFECTURE EARTHQUAKE USING THE EMPIRICAL GREEN'S FUNCTION METHOD}

\section{Takaaki IKEDA, Kazuhiro SOMEI, Susumu KURAHASHI, Ken MIYAKOSHI, Katsuhiro KAMAE, Yuya TAKASE and Yukiko KOJIMA}

A magnitude 6.6 of JMA scale earthquake occurred in central Tottori prefecture in Japan on 21 October 2016. The fault plane was estimated to be a high-angle left lateral fault with the strike of NNW-SSE direction from CMT solution and after-shock distribution. Strong ground motions were generated near source area and caused severe damage to many houses. This earthquake was generated at the area where an active fault has not been confirmed like 2000 Western Tottori prefecture earthquake of Mj7.3. We constructed a source model by the forward modeling using empirical Green's function method. The source parameters of strong motion generation area were determined from the comparisons of the synthesized broad-band ground motions with the observed ones at several stations including near source. Resultantly, we proposed source model with 2 strong motion generation areas. The relationship between seismic moment and short period level of acceleration source spectrum of this earthquake is expressed in a scaling law of the past study. 